\title{
Modified Application of Nitrogen Fertilizer for Increasing Rice Variety Tolerance toward Submergence Stress
}

\author{
Gribaldi Gribaldi, ${ }^{1}$ Nurlaili Nurlaili, ${ }^{1}$ Nurmala Dewi, ${ }^{1}$ Ekawati Danial, ${ }^{1}$ \\ Firnawati Sakalena, ${ }^{1}$ and Rujito A. Suwignyo ${ }^{2}$ \\ ${ }^{1}$ Faculty of Agriculture, University of Baturaja, Jl. Ratu Penghulu No. 02301, Karang Sari, Baturaja, South Sumatra 32115, Indonesia \\ ${ }^{2}$ Faculty of Agriculture, Sriwijaya University, Jl. Palembang-Prabumulih KM 32, Ogan Ilir, South Sumatra, Indonesia
}

Correspondence should be addressed to Gribaldi Gribaldi; gribaldi64@yahoo.co.id

Received 27 March 2017; Revised 2 June 2017; Accepted 4 June 2017; Published 10 July 2017

Academic Editor: Allen Barker

Copyright ( 2017 Gribaldi Gribaldi et al. This is an open access article distributed under the Creative Commons Attribution License, which permits unrestricted use, distribution, and reproduction in any medium, provided the original work is properly cited.

\begin{abstract}
This research was conducted from July to October 2015, using Randomized Block Design with two treatment factors and three replications for each treatment. The first factor was rice varieties (V): V1 = IR 64; V2 = Inpara 5. The second factor was fertilizer $(\mathrm{N})$ : N0: without submergence, all $\mathrm{N}$ fertilizer was given during planting; $\mathrm{N}$ : all $\mathrm{N}$ fertilizer dose was given during planting; and $\mathrm{N} 2$ : $1 / 2$ dose of $\mathrm{N}$ fertilizer was given during planting; the rest was given at 42 days after planting. The submergence was during 7-14 days after planting; N3 = the entire dose of $\mathrm{N}$ fertilizer that was given during planting, N4 =1/2 the dose of $\mathrm{N}$ fertilizer that was given during planting, and the rest was given at 42 days after planting. The submergence was during 7-14 and 28-35 days after planting. The results showed that the management of nitrogen fertilizer application had effect on rice growth and production which experienced dirty water submergence stress; the application of $1 / 2$ dose of $\mathrm{N}$ fertilizer given during planting had the best effect on rice growth and production; the longer the submergence period for rice variety, the higher the effect on rice growth and production.
\end{abstract}

\section{Introduction}

Food crop production, especially rice (Oryza sativa L.), should be increased in annual basis according to the increase of population growth. The increase of production can be done through productivity improvement at submergence stress prone areas which is considered as the main constraint in rice crop cultivation. The area of rice production centers which are mostly located in lowland areas would be extremely vulnerable to the growing possibility of flooding [1]. According to [2], submergence that causes stress on rice crop at South Asia and Southeast Asia areas was estimated of about 15 million hectares per year, whereas flood-prone rice field areas at South Sumatra were 124,465 ha [3].

Submergence stress on crop causes the obstacle of crop growth and production. Estimated yield loss due to flood was about 1.1 million tons of unhulled rice per year or equivalent to yield loss of 0.66 million tons of hulled rice [4]. In addition, [5] showed that rice crop which experienced submergence stress can decrease its grain yield with magnitude of $17.5 \%$ compared to the rice crop without submergence stress. One solution to overcome this problem is through development of high yield rice varieties that are tolerant to submergence stress.

As shown in Table 4, rice productivity in areas planted in this way is low and unstable, averaging $<2.0 \mathrm{tha}^{-1}$ in rainfed lowlands and $<1.5 \mathrm{tha}^{-1}$ in flood-prone areas, compared with yields of $>5.0 \mathrm{tha}^{-1}$ in input-intensive irrigated systems [6, 7]. This results in serious crop losses and sometimes leads to severe food shortages in flood-affected regions [8].

Rice variety of IR 64 was developed by IRRI in 2006 which was subsequently converted into IR 64 Sub-1 (Inpara 5) variety by transferring Sub-1 gene from FR13A species which is tolerant to submergence condition. This variety is able to decrease harvest loss risk during wet season due to unpredictable change of climate [2].

The decrease of unhulled rice yield due to the submergence for rice variety containing Sub-1 gene was lower than 
the rice variety which does not contain Sub-1 gene. The yield decrease on IR 64 rice variety $S u b-1$ was 16 percent, whereas IR 64 rice variety without $S u b-1$ gen was 39 percent [9]. According to [4], rice yield loss was about 30 percent due to the submergence condition and if this loss can be reduced to less than 10 percent through agronomical treatment, then it has high significant contribution for farmers and increment of national rice production.

In addition to the use of tolerant rice variety to submergence stress, proper fertilizing technique also can minimize the decrease of rice yield due to the submergence condition. Fertilizing treatment before crop was submerged might maintain crop survival at submergence condition. According to [10], $\mathrm{N}$ fertilizing might be a proper measure to minimize negative impact from submergence stress on crop. Management treatment of nitrogen fertilizer application will give significant effect on crop height and height increment rate of rice crop. These two parameters on rice crop usually will be more affected with submergence condition of more than three days [11]. The stem length increment rate during occurrence of submergence stress had significant effect on rice crop tolerance and crop recovery rate after submergence stress $[12,13]$. Moreover, study results by [14] showed that rice varieties given half dose of Urea during planting period added to $(\mathrm{Si}+\mathrm{Zn})$ fertilizer tend to show better vegetative and generative growths.

The research objective was to determine the best fertilization that can increase rice crop tolerance toward submergence stress.

\section{Materials and Methods}

2.1. Experiment Site. This research was conducted from July to October 2015 at Experimental Plot of Agricultural Faculty, Baturaja University. Research station is situated at altitude $13 \mathrm{~m}$ above mean sea level.

2.2. Experiment Design. The experimental design used in this research was Randomized Block Design with two treatment factors and three replications for each treatment as well as one crop clump for each treatment unit. The first factor was rice varieties $(\mathrm{V})$ consisting of V1 $=$ IR 64 and V2 = Inpara 5. The second factor was fertilizer $(\mathrm{N})$ treatments consisting of $\mathrm{N} 0$ = without submergence: that is, all $\mathrm{N}$ fertilizer was given during planting; N1: for submergence during 7-14 days after planting (DAP), $\mathrm{N}$ fertilizer was given during planting; $\mathrm{N} 2$ : for submergence during 7-14 DAP, 1/2 dose of $\mathrm{N}$ fertilizer was given during planting and the rest was given at $42 \mathrm{DAP}$; 3 : for submergence during 7-14 and 28-35 DAP, all N fertilizer dose was given during planting; N4: for submergence during 7-14 and 28-35 DAP, 1/2 dose of $\mathrm{N}$ fertilizer was given during planting and the rest was given at $42 \mathrm{DAP}$.

2.3. Implementation of Field Research. Rice variety seeds were incubated for 3 days and after germination period they were put into plastic trays media with dimension of $40 \mathrm{~cm}$ in length, $30 \mathrm{~cm}$ in width, and $13 \mathrm{~cm}$ in depth. These trays previously were filled with $15 \mathrm{~kg}$ of lowland swamp soil treated with fertilizers of $\mathrm{N}, \mathrm{P}, \mathrm{K}, \mathrm{Si}$, and $\mathrm{Zn}$ as well as manure at doses of $60,40,40,30$, and $20 \mathrm{~kg} \cdot \mathrm{ha}^{-1}$ as well as $10 \mathrm{ton} \cdot \mathrm{ha}^{-1}$, respectively [15]. Seeds of 21 days old within seedling trays were pulled out and planted in polybag plastic with one rice crop seed per polybag containing $10 \mathrm{~kg}$ of lowland swamp soil that had previously been submerged for about 30 days. These planting media were added to fertilizers as follows: full dose of $\mathrm{N}=46 \mathrm{~kg} \cdot \mathrm{ha}^{-1}$, half dose of $\mathrm{N}=23 \mathrm{~kg} \cdot \mathrm{ha}^{-1}$, SP 36 $=128 \mathrm{~kg} \cdot \mathrm{ha}^{-1}$, and $\mathrm{KCl}=100 \mathrm{~kg} \cdot \mathrm{ha}^{-1}$. These fertilizers were submerged into soil at depth of $10 \mathrm{~cm}$. Submergence was done by putting rice crops into tray that had been filled with dirty water (equivalent to $500 \mathrm{~g}$ soil/100 l water) with submergence period of 7 days. Minimum water submergence was $15 \mathrm{~cm}$ above plant surface. Rearing was in form of maintaining water submergence height during treatment period.

2.4. Yield and Observation. Observation of agronomical characteristics consisted of percentage of surviving plant (\%), plant height $(\mathrm{cm})$, number of productive tillers, numbers per clump, plant dry matter weight per clump (g), and grain yield per clump (g). Yield components consisted of number of grains per panicle, percentage of filled grains per panicle (\%), and 100-grain weight (g).

2.5. Statistical Analysis. Mean values were calculated for each of the measured variables, and ANOVA was used to assess the treatment effects. When ANOVA indicated a significant $F$ value, multiple comparisons of mean values were performed by the least significant difference test at $\alpha=0.05$. Relationship between variables observations is sought by correlation. Data were processed using SAS program Portable 9.1.3 for the $F$ test and SPSS 19 for correlation.

\section{Results}

3.1. Soil Chemical Properties Prior to Treatment. Analysis results of soil chemical properties prior to treatment (Table 2) showed that soil used in this research were lowland swamp soil with very acid reaction, low C-organic content, and low total-N content. Low availability of phosphorus nutrient and low K-dd in this soil showed that effort of fertilizer application could overcome low nutrients availability and could increase rice crop yield.

3.2. Percentage of Survive Plant. Percentage of live crops decreased in IR 64 varieties which experienced two times soaking $(\mathrm{N} 3, \mathrm{~N} 4)$ compared with one time soaking $(\mathrm{N} 1, \mathrm{~N} 2)$ (Table 2). While Inpara 5 varieties have a high percentage of live plants (100\%) despite having two times soaking. Percentage of live crops in treatment of IR 64 varieties treated with full $\mathrm{N}$ fertilization with immersion of 7-14 and 28-35 hst (V1N3) had the lowest live plant percentage, which was 66.7 percent.

3.3. Plant Height. With the stress of the soaking effects on plant height at 42 hst observation, plant height of rice varieties having two times soaking periods (N3, N4) decreased compared to one time immersion (N1, N2) (Table 3). Plant height of two rice varieties in the same immersion conditions was not significant for each fertilizer treatment but tended to 
differ significantly between the immersion treatments. Treatment of IR 64 varieties given full dose $\mathrm{N}$ fertilization with immersion of 7-14 and 28-35 hst (V1N3) had the lowest plant height of $85.2 \mathrm{~cm}$ and the greatest plant height in treatment was given by only $1 / 2$ the dose of $\mathrm{N}$ fertilizer at planting time, and the rest was administered at 42 hst with 7-14 hst immersion (V1N2), which was $108.3 \mathrm{~cm}$, and the plant height in this treatment showed no significant difference with nonimmersion treatment (V1N0).

3.4. Number of Productive Tillers. The number of productive tillers decreased in the rice varieties with two times immersion $(\mathrm{N} 3, \mathrm{~N} 4)$ compared to one time immersion $(\mathrm{N} 1$, N2) (Table 3). Two rice varieties experiencing the same immersion conditions resulted in a number of no significant difference productive tillers for each fertilization treatment, but significantly different for the immersion treatment. Treatment of IR 64 varieties given full dose of $\mathrm{N}$ fertilization with immersion of 7-14 and 28-35 hst (V1N3) had the lowest number of productive tillers, that is, 13.2 tillers, the highest number of tillers in the treatment of Inpara 5 was given 1/2 dose $\mathrm{N}$ fertilizer at planting time, and the rest was given at $42 \mathrm{hst}$ with immersion of 7-14 hst (V2N2), which was 30.8 tillers; besides, the number of productive tillers in this treatment showed no significant difference with treatment without immersion (V2N0).

3.5. Plant Dry Matter Weight. Plant dry matter weight was decreased in rice varieties with two times immersion (N3, N4) compared to one immersion (N1, N2) (Figure 1). Two rice varieties experiencing the same immersion conditions resulting in different dry weight of plants were not significant for each fertilization treatment but differed significantly for immersion treatment. Treatment of IR 64 varieties given full dose $\mathrm{N}$ fertilization with immersion of 7-14 and 28-35 hst (V1N3) had the lowest dry weight plant, that is, $37.5 \mathrm{~g} / \mathrm{clump}$, and highest dry weight in treatment Inpara 5 which was given $1 / 2$ fertilizer dose $\mathrm{N}$ at planting time, and the rest was administered at 42 hst with immersion of 7-14 hst (V1N2), which was 117,5 g/clump; besides, the amount of dry weight of plant in this treatment showed no significant difference with nonimmersion treatment (V2N0).

3.6. Yield and Yield Components. Arrangement of nitrogen fertilizer supply affects the yield and component of grain yield per clump. Results and components of grain yield per clump were decreased in rice varieties with two times immersion $(\mathrm{N} 3, \mathrm{~N} 4)$ compared to one immersion (N1, N2) (Figure 2 and Table 5). Treatment of IR 64 varieties given full dose $\mathrm{N}$ fertilization with immersion of 7-14 and 28-35 hst (V1N3) had the lowest grain yield, that is, $58.3 \mathrm{~g} / \mathrm{clump}$ and highest grain yield on treatment Inpara 5 which was given 1/2 dose $\mathrm{N}$ fertilizer at planting time, and the rest was given at $42 \mathrm{hst}$ with immersion of 7-14 hst (V1N2), which was $88.6 \mathrm{~g} / \mathrm{clump}$; besides, the grain yield on this treatment also showed no significant difference with nonimmersion treatment (V2N0).

Furthermore, there is a very strong relationship pattern between grain yield per clump with dry weight of plant per clump, with the equation $Y=55,137+0,259 X: R^{2}=0,817$

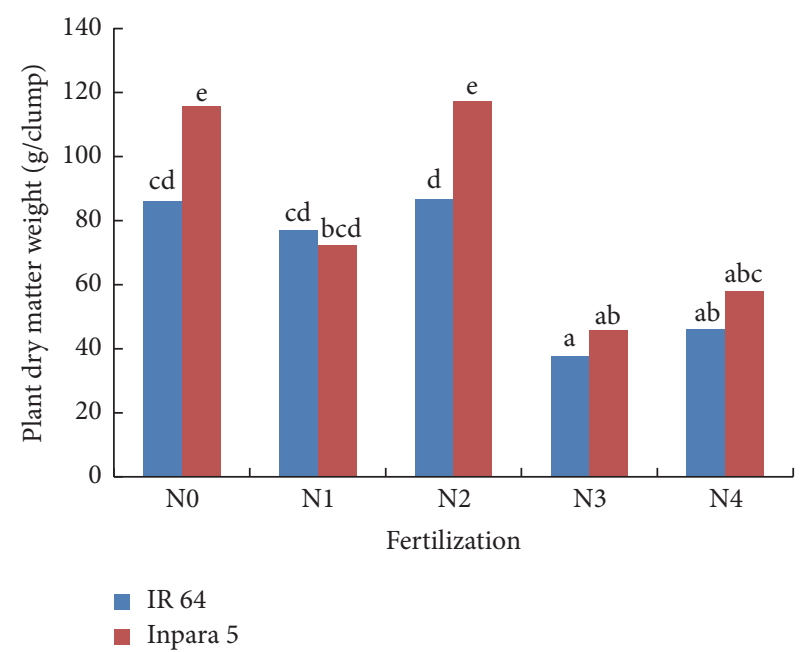

Figure 1: Plant dry matter weight at the end of research for two rice varieties and fertilizing treatment at condition of dirty water submergence stress. N0: without submergence, all N fertilizer was given during planting; N1: with submergence during 7-14 days after planting, $\mathrm{N}$ fertilizer was given during planting; $\mathrm{N}$ 2: with submergence during 7-14 days after planting, 1/2 dose of $\mathrm{N}$ fertilizer was given during planting and the rest was given at 42 days after planting; N3, with submergence during 7-14 and 28-35 days after planting, all $\mathrm{N}$ fertilizer dose was given during planting; N4: with submergence during 7-14 and 28-35 days after planting, 1/2 dose of $\mathrm{N}$ fertilizer was given during planting and the rest was given at 42 days after planting. Numbers followed by the same characters are not significantly different at least significant difference or $\mathrm{LSD}_{0.05}: 27.9$.

TABLE 1: Analysis results of soil properties before treatment.

\begin{tabular}{lccc}
\hline Analyses & Unit & Result & Status \\
\hline $\mathrm{pH} \mathrm{H} \mathrm{H}_{2} \mathrm{O}$ & & 4.03 & Very acidic \\
C-organic & $\%$ & 1.82 & Low \\
N-total & $\%$ & 0.17 & Low \\
P-Bray I & $\mathrm{ppm}$ & 13.65 & Low \\
$\mathrm{K}$-dd & $\mathrm{me} \cdot 100 \mathrm{~g} \mathrm{~g}^{-1}$ & 0.26 & Low \\
$\mathrm{Na}$ & $\mathrm{me} \cdot 100 \mathrm{~g}^{-1}$ & 0.22 & Low \\
$\mathrm{Ca}$ & $\mathrm{me} \cdot 100 \mathrm{~g} \mathrm{~g}^{-1}$ & 1.30 & Very low \\
$\mathrm{Mg}$ & $\mathrm{me} \cdot 100 \mathrm{~g}^{-1}$ & 0.25 & Very low \\
$\mathrm{CEC}$ & $\mathrm{me} \cdot 100 \mathrm{~g}^{-1}$ & 13.08 & Low \\
Al-dd & $\mathrm{me} \cdot 100 \mathrm{~g} \mathrm{~g}^{-1}$ & 1.00 & Very low \\
\hline
\end{tabular}

Source: Soil Science Laboratory, Faculty of Agriculture, Unsri, 2015.

(Figure 3). The higher the dry weight of the plant, the higher the yield of grain obtained.

\section{Discussion}

Analysis results of soil chemical properties prior to treatment (Table 1) showed that soil used in this research was lowland swamp soil with very acid reaction, low C-organic content, and low total-N content. Low availability of phosphorus 


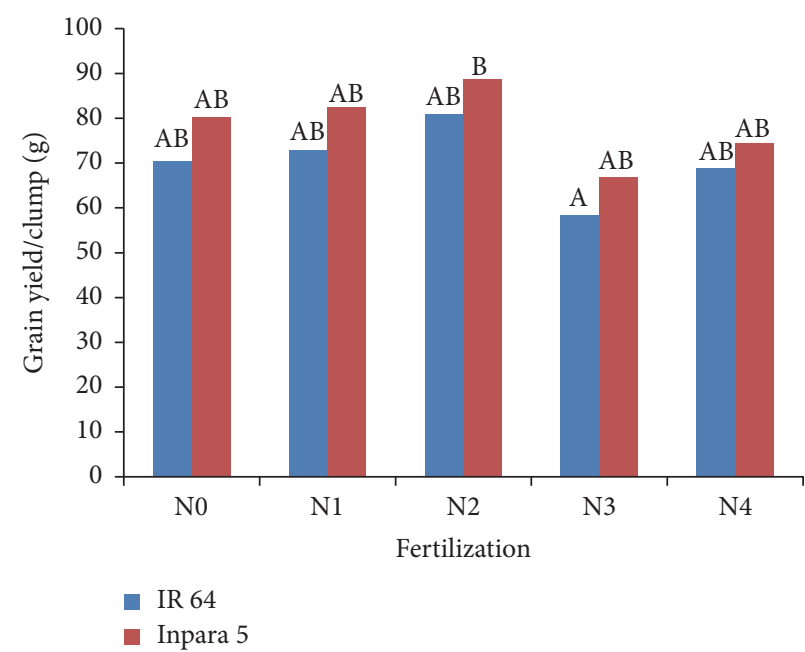

(a)

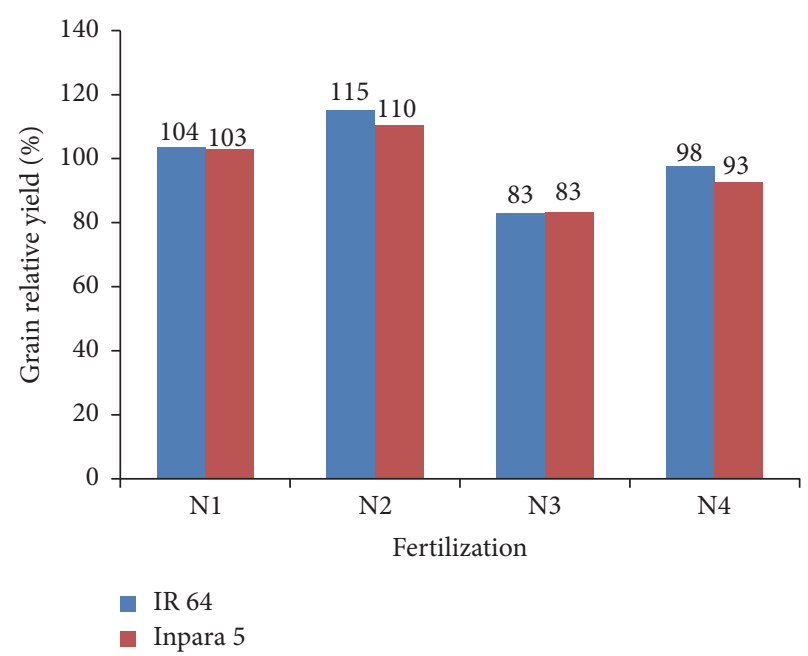

(b)

FIGURE 2: Fertilizing treatment effect for two rice varieties on grain yield (a) and relative grain yield (b) at condition of dirty water submergence stress. N0: without submergence, all N fertilizer was given during planting; N1: for submergence during 7-14 days after planting, N fertilizer was given during planting; N2: for submergence during 7-14 days after planting, 1/2 dose of $\mathrm{N}$ fertilizer was given during planting and the rest was given at 42 days after planting; N3: for submergence during 7-14 and 28-35 days after planting, all N fertilizer dose was given during planting; N4: for submergence during 7-14 and 28-35 days after planting, 1/2 dose of $\mathrm{N}$ fertilizer was given during planting and the rest was given at 42 days after planting. Numbers followed by the same characters are not significantly different at least significant difference or $\mathrm{LSD}_{0.05}$ : 28.7.

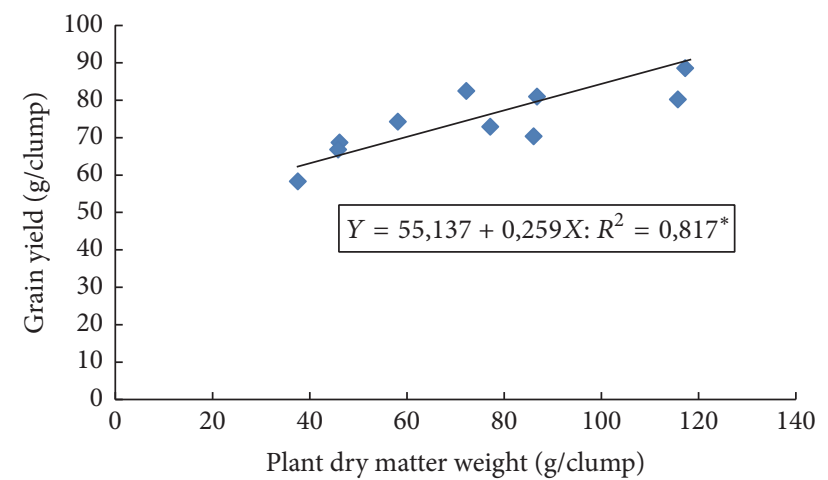

FIGURE 3: Relationship pattern between plant dry matter weight and grain yield. ${ }^{*} R^{2}=0,817$ is the value of the goodness of fit between grain yield per clump and dry weight of plant per clump.

nutrient and low K-dd in this soil showed that effort of fertilizer application could overcome low nutrients availability and could increase rice crop yield.

The immersion stress has an effect on the tolerance, growth, and yield of grain per clump of rice plants, as seen from the changes of life plant percentage, plant height, number of productive tillers, dry weight of plant and also some components of yield.

Crop tolerance is the ability of plants to avoid or reduce damage to crops with the presence of soaking stress so as to grow and produce as in plants that do not experience the immersion stress. The longer and more frequent the rice plants experience soaking stress, the greater the damage that occurs in plants. The regulation of $\mathrm{N}$ fertilizer application
TABLE 2: Percentage of survive plant (\%) of two rice varieties and fertilizing treatment in condition of dirty water submergence stress.

\begin{tabular}{lccccc}
\hline Treatment & $\mathrm{N} 0$ & $\mathrm{~N} 1$ & $\mathrm{~N} 2$ & $\mathrm{~N} 3$ & $\mathrm{~N} 4$ \\
\hline IR 64 & $100.0^{\mathrm{b}}$ & $100.0^{\mathrm{b}}$ & $100.0^{\mathrm{b}}$ & $66.7^{\mathrm{a}}$ & $83.3^{\mathrm{ab}}$ \\
Inpara 5 & $100.0^{\mathrm{b}}$ & $100.0^{\mathrm{b}}$ & $100.0^{\mathrm{b}}$ & $100.0^{\mathrm{b}}$ & $100.0^{\mathrm{b}}$ \\
\hline
\end{tabular}

Notes. N0: without submergence, all $\mathrm{N}$ fertilizer was given during planting; N1: with submergence during 7-14 days after planting, N fertilizer was given during planting; N2: with submergence during 7-14 days after planting, $1 / 2$ dose of $N$ fertilizer was given during planting and the rest was given at 42 days after planting; N3: with submergence during 7-14 and 28-35 days after planting, all $\mathrm{N}$ fertilizer dose was given during planting; $\mathrm{N} 4$ : with submergence during 7-14 and 28-35 days after planting, 1/2 dose of $\mathrm{N}$ fertilizer was given during planting and the rest was given at 42 days after planting. Numbers followed by the same characters are not significantly different at least significant difference or $\mathrm{LSD}_{0.05}: 26.4$.

statistically was not significant but it showed a tendency of increasing the percentage of live plants by 16.6 percent. According to [10], $\mathrm{N}$ fertilizer application was the proper measure to decrease negative effect of submergence stress on crop. Moreover, according to [16], recovery capacity highly depends on plant capability to adapt quickly to certain condition after they experience flooding stress. In addition, [4] stated that better recovery for rice plant which experienced submergence stress was indicated by faster new tillers emergence so that plant had relatively same tiller numbers or even higher tiller numbers than that of plant which did not experience submergence stress.

Management of $\mathrm{N}$ fertilizer application had effect on rice plant height. Rice variety which was treated with half dose of $\mathrm{N}$ fertilizer during planting time (and the rest was given at 
TABle 3: Plant height $(\mathrm{cm})$ at 42 days after planting of two rice varieties and fertilizing treatment at condition of dirty water submergence stress.

\begin{tabular}{lccccc}
\hline Treatment & $\mathrm{N} 0$ & $\mathrm{~N} 1$ & $\mathrm{~N} 2$ & $\mathrm{~N} 3$ & $\mathrm{~N} 4$ \\
\hline IR64 & $107.0^{\mathrm{ab}}$ & $104.2^{\mathrm{ab}}$ & $108.3^{\mathrm{b}}$ & $85.2^{\mathrm{a}}$ & $99.3^{\mathrm{ab}}$ \\
Inpara 5 & $109.1^{\mathrm{ab}}$ & $103.5^{\mathrm{ab}}$ & $107.5^{\mathrm{ab}}$ & $90.7^{\mathrm{ab}}$ & $101.0^{\mathrm{ab}}$ \\
\hline
\end{tabular}

Notes. N0: without submergence, all $\mathrm{N}$ fertilizer was given during planting; $\mathrm{N} 1$ : with submergence during 7-14 days after planting, $\mathrm{N}$ fertilizer was given during planting; N2: with submergence during 7-14 days after planting, 1/2 dose of $\mathrm{N}$ fertilizer was given during planting and the rest was given at 42 days after planting; N3: with submergence during 7-14 and 28-35 days after planting, all $\mathrm{N}$ fertilizer dose was given during planting; $\mathrm{N} 4$ : for submergence during 7-14 and 28-35 days after planting, 1/2 dose of $\mathrm{N}$ fertilizer was given during planting and the rest was given at 42 days after planting. Numbers followed by the same characters are not significantly different at least significant difference or $\mathrm{LSD}_{0.05}: 22.8$.

TABle 4: Productive tiller numbers of two rice varieties and fertilizing treatment at condition of dirty water submergence stress.

\begin{tabular}{lccccc}
\hline Treatment & $\mathrm{N} 0$ & $\mathrm{~N} 1$ & $\mathrm{~N} 2$ & $\mathrm{~N} 3$ & $\mathrm{~N} 4$ \\
\hline IR64 & $26.0^{\mathrm{c}}$ & $25.2^{\mathrm{bc}}$ & $25.7^{\mathrm{c}}$ & $13.2^{\mathrm{a}}$ & $15.8^{\mathrm{a}}$ \\
Inpara 5 & $27.7^{\mathrm{c}}$ & $26.7^{\mathrm{c}}$ & $30.8^{\mathrm{c}}$ & $16.7^{\mathrm{a}}$ & $18.7^{\mathrm{ab}}$ \\
\hline
\end{tabular}

Notes. N0: without submergence, all $\mathrm{N}$ fertilizer was given during planting; N1: with submergence during 7-14 days after planting, $\mathrm{N}$ fertilizer was given during planting; N2: with submergence during 7-14 days after planting, $1 / 2$ dose of $N$ fertilizer was given during planting and the rest was given at 42 days after planting; N3: with submergence during 7-14 and 28-35 days after planting, all $\mathrm{N}$ fertilizer dose was given during planting; $\mathrm{N} 4$ : with submergence during 7-14 and 28-35 days after planting, 1/2 dose of $\mathrm{N}$ fertilizer was given during planting and the rest was given at 42 days after planting. Numbers followed by the same characters are not significantly different at least significant Difference or $\mathrm{LSD}_{0.05}:$ 7.0.

TABLE 5: The fertilizing effect for two rice varieties on several yield components at condition of dirty water submergence stress.

\begin{tabular}{lcccccc}
\hline \multirow{2}{*}{ Treatment } & \multicolumn{3}{c}{ Inpara 5 } & \multicolumn{3}{c}{ IR64 } \\
& 1 & 2 & 3 & 1 & 2 & 3 \\
\hline N0 & 130.8 & 93.0 & 2.39 & 128.5 & 91.0 & 2.49 \\
N1 & 123.2 & 90.1 & 2.37 & 118.7 & 91.7 & 2.38 \\
N2 & 128.9 & 93.2 & 2.36 & 129.7 & 92.6 & 2.42 \\
N3 & 101.3 & 89.5 & 2.32 & 110.8 & 89.2 & 2.37 \\
N4 & 112.3 & 91.8 & 2.44 & 122.1 & 91.1 & 2.41 \\
\hline
\end{tabular}

Remarks: 1: the number of grains per panicle (grains), 2: percentage of grain pithy (\%), 3: grain weight of 100 grains (g). N0: without submergence, all $\mathrm{N}$ fertilizer was given during planting; $\mathrm{N} 1$ : with submergence during 7-14 days after planting, $\mathrm{N}$ fertilizer was given during planting; $\mathrm{N} 2$ : with submergence during 7-14 days after planting, 1/2 dose of $\mathrm{N}$ fertilizer was given during planting and the rest was given at 42 days after planting; N3: with submergence during 7-14 and 28-35 days after planting, all $\mathrm{N}$ fertilizer dose was given during planting; N4: with submergence during 7-14 and 28-35 days after planting, 1/2 dose of $\mathrm{N}$ fertilizer was given during planting and the rest was given at 42 days after planting.

42 days after planting) either received one time submergence or two times submergence and tends to have higher plant height than that of other fertilizing treatments. IR 64 rice variety even with one time submergence had higher plant height than without submergence treatment with magnitude of $107.5 \mathrm{~cm}$. According to [11], management of $\mathrm{N}$ fertilizer application had effect on plant height and increment rate of plant height. In addition, [12] stated that plant height after flooding stress period was more affected by rice variety than by fertilization treatment. The papers [17-19] also stated that the increase in plant height becomes more noticeable with prolonged submergence.

Rice varieties which experienced submergence stress treated with half dose of $\mathrm{N}$ fertilizer during planting time (and the rest was given at 42 days after planting) tend to have higher plant dry matter weight than that of other fertilizing treatments; even IR 64 and Inpara 5 varieties which experienced one time submergence tend to have higher plant dry matter weight than that of without submergence with magnitude of $86.7 \mathrm{~g}$ and $117.2 \mathrm{~g}$, respectively. This was due to the fact that varieties treated with this fertilizer had higher plant height and higher tiller numbers than the other fertilizing treatments so that dry matter weight of these varieties was also high. According to [20], the weight increasing of plant dry is an indicator of growth and development of increasing plant. In addition, [21] stated that postsubmergence stem dry weight correlated positively and strongly with survival $(r=$ 0,97).

Inpara 5 variety treated with half dose of $\mathrm{N}$ fertilizer during planting time (and the rest was given at 42 days after planting) showed higher grain yield than that of other treatments, either for one time submergence or for two times submergence with grain yield of $88.6 \mathrm{~g}$ and $73.4 \mathrm{~g}$, respectively. This was in accordance with high change of plant dry matter weight in this treatment resulting in high capability of plant to distribute assimilates into generative organ so that stem can produce more full grain which was shown by the change of several yield components on this treatment (Table 5). Study results from [22] showed that fertilization with half dose of Urea fertilizer during planting as well as $\mathrm{Si}$ and $\mathrm{Zn}$ in which the remainder was applied at 42 days after planting had produced the highest grain yield for all tested varieties for flooding period of 7 to 14 days after planting.

Moreover, there was very close relationship pattern between grain yield per clump and plants dry matter weight per clump expressed by equation of $Y=55.137+0.259 X$ : $R^{2}=0.817$ (Figure 3). The higher the plants dry matter weight, the higher the obtained grain yield. In addition, the research result of [23] reported that the grain yield also has very real relationship to the nitrogen content.

\section{Conclusions}

The results showed that management of nitrogen fertilizer application had effect on rice growth and production which experienced dirty water submergence stress. Application of half dose of $\mathrm{N}$ fertilizer during planting time (and the rest was given at 42 days after planting) was the best treatment in terms of rice growth and production. The longer the submergence period on rice variety, the bigger the effect on rice growth and production.

\section{Conflicts of Interest}

The authors declare that they have no conflicts of interest. 


\section{Acknowledgments}

The authors especially wish to acknowledge the Ministry of Research, Technology and Higher Education that had already provided funding for this research through Competitive Research Grant (Hibah Bersaing) for fiscal year of 2015.

\section{References}

[1] C. Aydinalpn and M. S. Cresser, "The effect of global climate change on agriculture," American-Eurasian Journal of Agricultural \& Environmental Sciences, vol. 3, pp. 672-676, 2008.

[2] E. M. Septiningsih, A. M. Pamplona, D. L. Sanchez et al., "Development of submergence-tolerant rice cultivars: the Sub1 locus and beyond," Annals of Botany, vol. 103, no. 2, pp. 151-160, 2009.

[3] Badan Perencanaan Pembangunan Nasional (Bappenas), "Indonesia Climate Change Sectoral Roadmap (ICCSR) of agrcultural sector," Tech. Rep., 2010, http://bappenas.go.id.

[4] A. K. Makarim, E. Suhartatik, G. R. Pratiwi, and Ikhwani, "Assembly of rice production technology on swamp land and flooding prone swamp ( $>15$ days) for minimum productivity of $7 \mathrm{t} \mathrm{ha} \mathrm{h}^{-1}$, A Final Report of ROPP DIPA, Indonesian Rice Research Institute. Indonesian Agricultural Research and Development, 2009.

[5] Ikhwani, "Resistency of submergence tolerant rice variety and its response to fertilizers," Jurnal Lahan Suboptimal, vol. 2, no. 1, pp. 1-13, 2013.

[6] A. M. Ismail, U. S. Singh, S. Singh, M. H. Dar, and D. J. Mackill, "The contribution of submergence-tolerant (Sub1) rice varieties to food security in flood-prone rainfed lowland areas in Asia," Field Crops Research, vol. 152, pp. 83-93, 2013.

[7] U. S. Singh, M. H. Dar, S. Singh et al., "Field performance, dissemination, impact and tracking of submergence tolerant (Sub1) rice varieties in South Asia," Sabrao Journal of Breeding and Genetics, vol. 45, no. 1, pp. 112-131, 2013.

[8] D. J. Mackill, A. M. Ismail, U. S. Singh, R. V. Labios, and T. R. Paris, "Development and rapid adoption of submergencetolerant (Sub1) rice varieties," Advances in Agronomy, vol. 115, pp. 299-352, 2012.

[9] IRRI and The Research and Development Council of Food Crops, Submergence Tolerant Rice, Food Crops Research and Development Center, 2009.

[10] S. T. Reed and G. G. Gordon, "Nitrogen fertilization effects on recovery of bush beans from flooding," International Journal of Vegetable Science, vol. 14, no. 3, pp. 256-272, 2008.

[11] R. A. Suwignyo, F. Zulvica, and Hendryansyah, “Technological adaptation for rice production at lowland swamp area: the effort to prevent the negative effect of rice crop flooding through regulation of nitrogen fertilizer application," in Proceedings of the 3rd National Seminar on Rice Day, Indonesian Rice Research Institute, Sukamandi, Indonesia, July 2008.

[12] R. A. Gribaldi, M. Suwignyo, R. Hasmeda, and R. Hayati, "The effect of fertilization on morphophysiological changes of two rice varieties under submergence stress," Jurnal Agronomi Indonesia, vol. 42, no. 1, pp. 17-23, 2014.

[13] R. A. Suwignyo, F. Zulvica, and L. Hakim, "The response of several rice varieties to nitrogen treatment in seedling and silica application through coal ash residue," in Proceedings of the 3rd National Seminar on Rice Day, Indonesian Rice Research Institute, Sukamandi, Indonesia, July 2008.
[14] R. A. Gribaldi, M. Suwignyo, R. Hasmeda, and R. Hayati, "The arrangement of nitrogen fertilizer application to increase the rice plant tolerance and recovery to the submerged stress," Jurnal Lahan Suboptimal, vol. 2, no. 2, pp. 151-158, 2013.

[15] R. A. Suwignyo, A. Wijaya, H. Sihombing, and G. Gribaldi, "Modification of nutrients application to improve rice seeds vigor in submergence condition," Jurnal Lahan Suboptimal, vol. 1, no. 1, pp. 1-11, 2012.

[16] Gribaldi, R. A. Suwignyo, M. Hasmeda, and R. Hayati, "Fertilization strategy to increase rice growth and production under two flooding condition on two lowland swamp types," Agrivita, vol. 38, no. 1, pp. 64-72, 2016.

[17] A. Anandan, G. Rajiv, A. Ramarao, and M. Prakash, "Internode elongation pattern and differential response of rice genotypes to varying levels of flood water," Functional Plant Biology, vol. 39, no. 2, pp. 137-145, 2012.

[18] B. Wang, Y. J. Zhou, Y. Z. Xu, G. Chen, Q. F. Hu, and W. G. Wu, "Effect effects of waterlogging stress on growth and yield of middle season rice at the tillering stage," China Rice, vol. 20, pp. 68$75,2014$.

[19] M. B. Jackson, "Ethylene-promoted elongation: an adaptation to submergence stress," Annals of Botany, vol. 101, no. 2, pp. 229248, 2008.

[20] E. Mungara, D. Indradewa, and R. Rogomulyo, "Analysis of growth and rice yields (Oryza sativa L.) conventional, organic transitional and organic farming system," Jurnal Vegetalika, vol. 2, no. 3, pp. 1-12, 2013.

[21] S. Singh, D. J. Mackill, and A. M. Ismail, "Physiological basis of tolerance to complete submergence in rice involves genetic factors in addition to the SUB1 gene," AoB PLANTS, vol. 6, Article ID plu060, 2014.

[22] Gribaldi, Agronomical treatment to increase rice crop's tenacity and recovery toward submergence stress [Ph.D. thesis], Faculty of Agriculture, Sriwijaya University, Palembang, Indonesia, 2013.

[23] Y. Zhang, Z. Wang, L. Li et al., "Short-term complete submergence of rice at the tillering stage increases yield," PLOS ONE, vol. 10, no. 5, Article ID e0127982, 2015. 


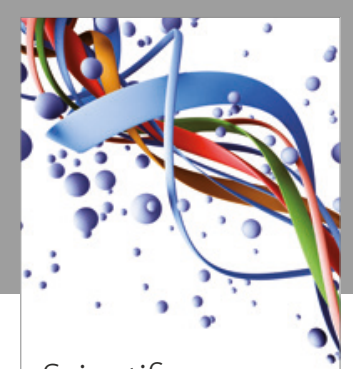

Scientifica
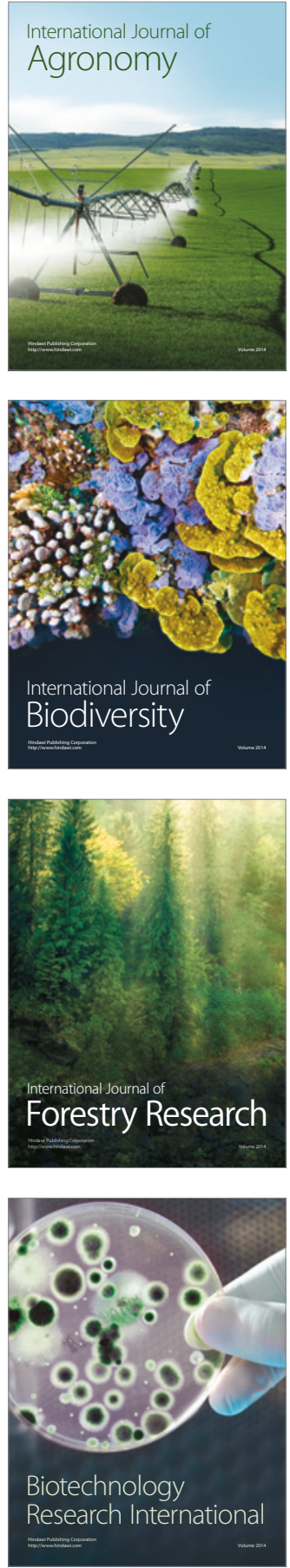
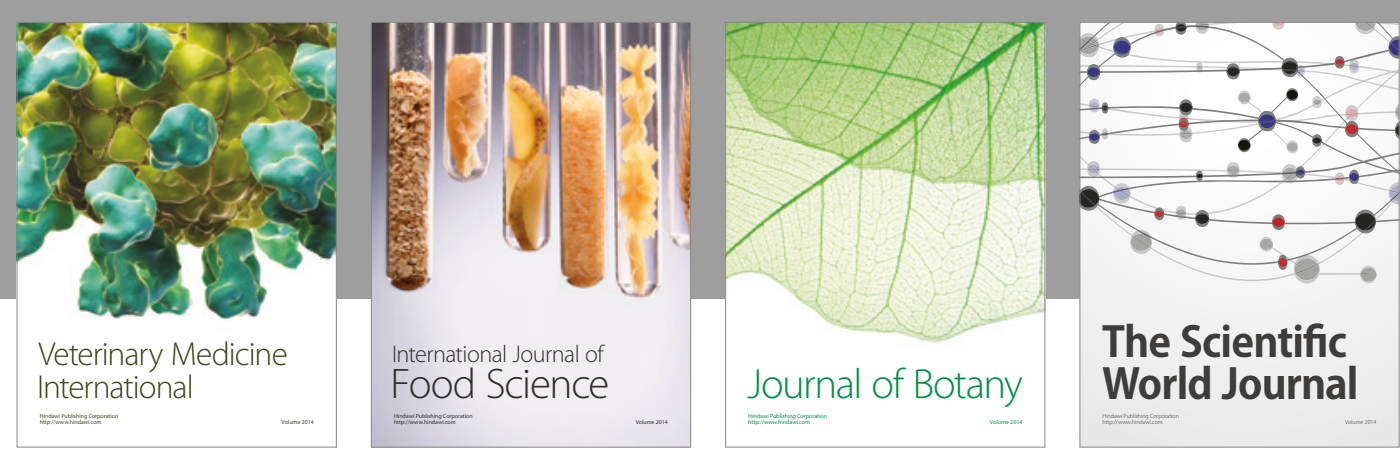

The Scientific

\section{World Journal}

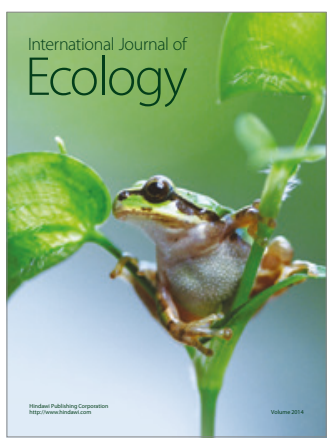

\section{Hindawi}

Submit your manuscripts at

https://www.hindawi.com
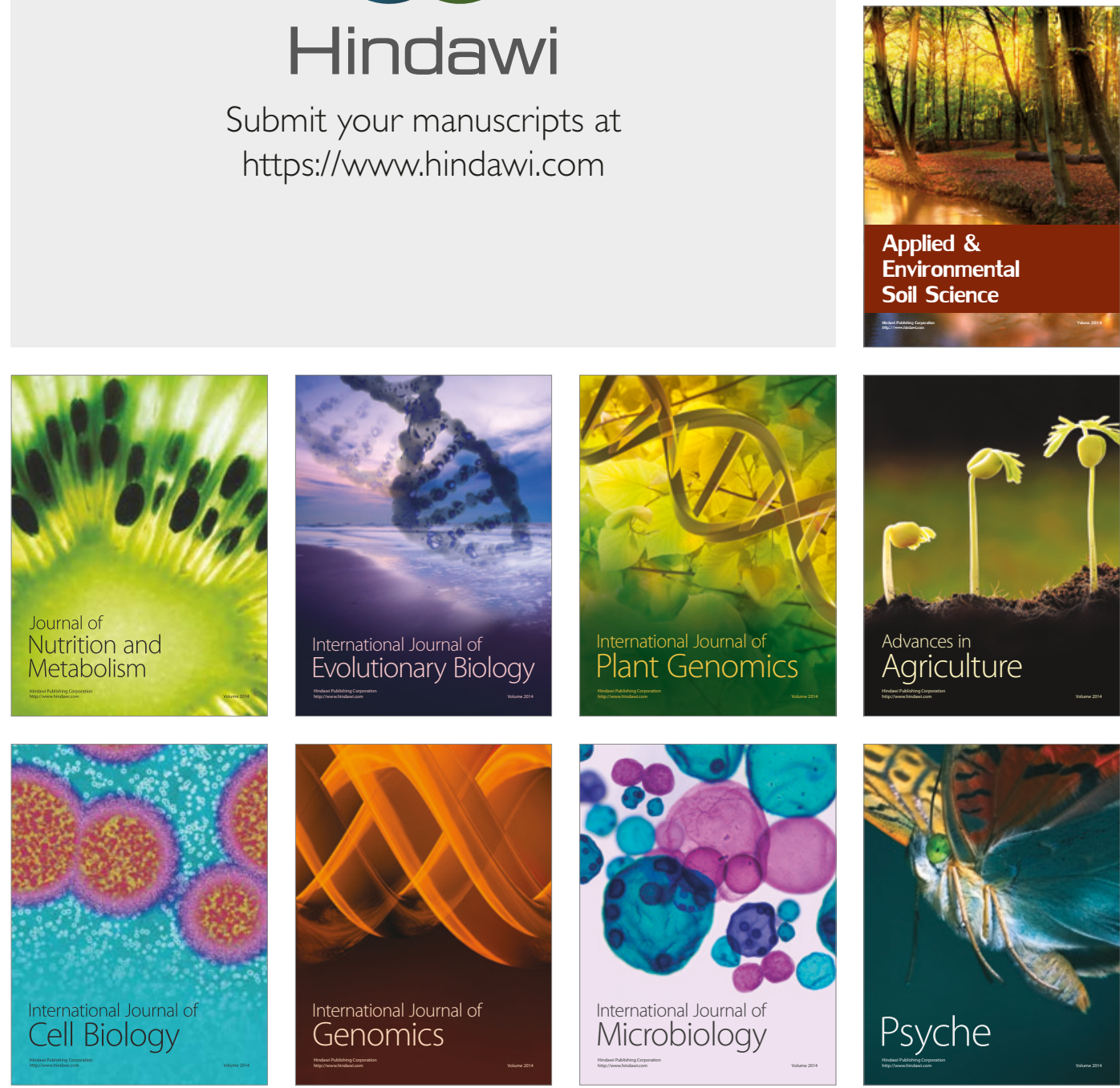

hternational Journal of Microbiology
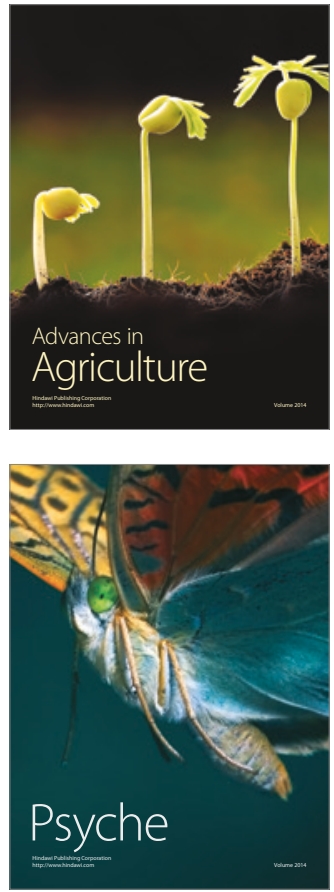